\title{
Does One Size Fit All? Patents, the Right to Health and Access to Medicines
}

\author{
Jennifer Anna Sellin ${ }^{1}$
}

Published online: 14 December 2015

(C) The Author(s) 2015. This article is published with open access at Springerlink.com

\begin{abstract}
The question posed in this article is whether the right to health and patents conflict or coexist. This question is examined from the perspective of the issue of access to affordable medicines in developing countries focusing on the right to health as set out in the ICESCR and patent standards (and flexibilities) as required by the TRIPS Agreement. In the strict sense, there is no conflict between the right to health and patents. ICESCR and TRIPS do not contain mutually exclusive obligations. Yet, it is shown that tension between the two does exist. There are a number of ways in which such tension can be resolved. The UN Sub-Commission for the Promotion and Protection of Human Rights has contended that human rights should enjoy primacy over patents, yet there is no evidence to suggest that the right to health and/or access to essential medicines are considered prioritised norms under international law. The WTO disagrees and views IPRs and human rights as complementary. In international law there is a strong presumption against conflict. In line with the principle of systemic integration a good faith interpretation of the relevant WTO and human rights provisions should lead to a reading of TRIPS' obligations which is coherent with human rights law. However, this balancing act must also take place at the domestic level and the success of such a coexistence approach, namely whether (developing) states are able to strike a balance between access to medicines and patent protection, will depend much on the actual implementation and interpretation by states. Consequently, some examples of state
\end{abstract}

\footnotetext{
This article is based on part of the author's PhD research, published as Jennifer Sellin, Access to Medicines. The Interface between Patents and Human Rights: Does One Size Fit All? School of Human Rights Research Series Vol. 64 (Intersentia, Cambridge 2014).
}

Jennifer Anna Sellin

jennifer.sellin@maastrichtuniversity.nl

1 Department of International and European Law, Maastricht University,

Maastricht, The Netherlands 
practice regarding the interpretation and implementation of TRIPS in light of the right to health are highlighted.

Keywords Access to medicines - Right to health - Patents - TRIPS - Conflict · Coexistence

\section{Introduction}

Worldwide poor patients continue to face difficulties in obtaining or purchasing essential medicines because of scarce availability and high prices. According to the intuitive estimate of the World Health Organisation (WHO) at least one-third of the world's population have no regular access to medicines. ${ }^{1}$ The Millennium Development Goals (MDG) Gap Task Force has stated that 'the cost of many essential medicines, especially those for chronic diseases, remains prohibitive in many developing countries'. ${ }^{2}$

Public health and (the lack of) access to affordable medicines are global issues. The role of intellectual property rights (IPRs), more specifically patents, in that regard has been an issue of considerable debate for quite some time. The issue is complex and multifaceted. A wide variety of factors contribute to the problem of the lack of access to affordable medicines, from inadequate health care systems, limited resources to corruption. This article limits itself to the (additional) impact of patent protection on access. The argument often made in that regard is that patent protection for medicines results in higher medicine prices and, thus, negatively impacts patients' access to medicines. Both economic theory (the fact that patent protection in the majority of situations leads to a monopoly position) and empirical studies find that in general patent protection for medicines goes hand in hand with higher medicine prices. ${ }^{3}$

These higher prices are then justified, particularly by the pharmaceutical industry, as essential in order to recoup their substantial research and development costs. Thus, it is argued that without patent protection companies would have no incentive to invest in innovation. ${ }^{4}$ Although the incentive to innovate function of patent protection is not contested here, an important observation must be made. Patent protection only provides an incentive to innovate in situations where the innovator has a real possibility to recoup its investment, i.e. a profitable market. Unfortunately, though, the majority of patients in developing countries, lacking resources, do not provide such a profitable market. As a result the largest part of health-related research and development is invested in treatments for diseases that affect patients worldwide (such as cancer or diabetes) or are targeted mainly towards patients in the developed world (such as the 'female viagra' Addyi to treat

\footnotetext{
${ }^{1}$ WHO (2011), p. 8. See further Cameron et al. (2009).

2 MDG Gap Task Force (2012), p. 64.

${ }^{3}$ CIPR (2002), pp. 36 et seq.; Scherer and Watal (2001), pp. 5 et seq. See also Maskus (2009); Borrell (2007); Li (2008). Contra: Attaran (2004).

${ }^{4}$ CIPR (2002), pp. 29-30; International Federation of Pharmaceutical Manufacturers and Associations (2012), p. 50.
} 
female sexual dysfunction which has recently been approved in the US). ${ }^{5}$ What is lacking, however, is research and development targeted at diseases primarily prevalent in developing countries, also referred to as neglected and poverty-related diseases. ${ }^{6}$

As such the problem with regard to access to medicines is two-fold in that patients lack access to existing medicines that are (globally) available but for a variety of reasons do not reach the patient in need, and the lack of research into and the development of new medicines for diseases especially prevalent in developing countries could lead to a decline in available treatments in the long term.

The issue of access to medicines lies at the crossroads between the systems of international human rights law, intellectual property (IP) and trade law. In recent years there has been a continuous expansion of IPRs, both in their subject matter and scope. Part of this is due to the development of new technologies in the last few decades and the resulting growing demand for new forms of legal protection by the content owners and business. ${ }^{7}$ With the linking of IP to trade through the adoption of the Agreement on Trade-Related Aspects of Intellectual Property Rights (TRIPS) as an annex to the Agreement establishing the World Trade Organisation (WTO) of 1994, IP is now part of the WTO framework. The move to link IP with trade has been criticised. $^{8}$

Not only the international IP system but also the international human rights system has experienced expansion. Although the International Covenant on Economic, Social and Cultural Rights (ICESCR) was adopted at the same time as the International Covenant on Civil and Political Rights (ICCPR), namely in 1966, economic, social and cultural rights for a long time did not receive the same form of recognition as civil and political rights. The work done in conceptualising and clarifying socio-economic rights, through for example the adoption of General Comments by treaty monitoring bodies but also within academia, has led to a refinement of the rights of individuals and states' obligations under international human rights law.

This expansion has led to a blurring of the demarcation between the two fields, creating dense policy spaces where previously unrelated sets of principles, norms and rules increasingly overlap in incoherent and inconsistent ways. ${ }^{9}$ There has been increasing recognition from a human rights perspective of the impact of the WTO regime on issues going beyond trade, such as economic, social and environmental concerns. $^{10}$ This, however, is a relatively recent phenomenon. Within the international trade community, human rights are not prominently visible. Issues

\footnotetext{
5 See Boseley (2015).

6 MDG Gap Task Force (2012), p. 71; CIPR (2002), pp. 29-30. See further Trouiller et al. (2002); Chirac and Torreele (2006).

7 Helfer (2007), p. 973.

8 See for example Muzaka (2009), p. 1343.

9 See for a discussion on such regime expansion, Helfer (2007), pp. 980-982.

${ }^{10}$ Harrison (2007), p. 36. See further Grosse Ruse-Kahn (2009).
} 
of social justice are rarely discussed in WTO bodies, and if they are, reference is not made to the human rights discourse. ${ }^{11}$

It is only in the last two decades that an increasing awareness can be seen among academics, non-governmental organisations (NGOs) and international bodies of the different intersections of trade, IP and human rights. For example, in 1996 South Africa amended its Medicines Act to promote access to medicines when 39 pharmaceutical companies filed a suit challenging the amendments arguing that they would destroy patent protection and, thus, were inconsistent with TRIPS. The US supported the companies' claim and put South Africa on its 'watch list', a list drawn up by the US Trade Representative to signal countries, and permitting the US President to demand action against such countries, which portray unjustifiable or unreasonable trade practices, specifically including IP issues. The case was taken up by South Africa's civil society and received widespread international attention and as a result was withdrawn in April 2001. ${ }^{12}$

There are two distinct conceptual approaches with respect to the interface between IP and human rights: the conflict and coexistence approach. ${ }^{13}$ Some find that IPRs and human rights are in fundamental conflict with each other. This view sees strong IP protection as undermining a range of human rights obligations, especially with respect to socio-economic rights. ${ }^{14}$ The United Nations (UN) SubCommission on the Protection and Promotion of Human Rights, for example, stated that 'there are apparent conflicts between the intellectual property rights regime embodied in the TRIPS Agreement, on the one hand, and international human rights law, on the other'. ${ }^{15}$ In the case of access to medicines, patent protection for pharmaceutical products is seen to undermine the right to health and life. Proponents of this approach argue that to resolve such a conflict the normative primacy of human rights law over IP law must be recognised in situations where treaty obligations conflict. ${ }^{16}$ Others disagree and consider human rights and IPRs to be essentially compatible. They see 'both areas of law as concerned with the same fundamental question: defining the appropriate scope of private monopoly power that gives authors and inventors sufficient incentive to create and innovate, while ensuring that the consuming public has adequate access to the fruits of their efforts'. ${ }^{17}$ In short, the question here is how to strike a fair balance between

\footnotetext{
11 Harrison (2007), p. 36; Papadopoulou (2011), p. 271.

12 Kramer (2007), pp. 167-168. See further Sell (2001-2002), pp. 501-502; Hassim et al. (2007), p. 452.

13 Yu (2007), pp. 709-710; Helfer (2003), pp. 47-48; Haugen (2007), p. 102.

14 Helfer (2003), p. 48.

15 UN Sub-Commission on the Promotion and Protection of Human Rights, 'Resolution 2000/7. Intellectual Property Rights and Human Rights', UN Doc. E/CN.4/SUB.2/RES/2000/7, para. 2.

16 See further Cullet (2003), pp. 157-159; Durojaye (2008), p. 69; Meier (2006), pp. 729 et seq.; Dommen (2002).

17 Helfer (2003), p. 48.
} 
incentives, on the one hand, and access on the other. Thus, according to the latter approach, human rights and IPRs can be considered to be compatible; although there are differing views on how exactly the balance between the two should be struck. $^{18}$

This article will address this question-whether human rights and IPRs conflict or coexist-from the perspective of the issue of access to affordable medicines in developing countries focusing on the right to health as set out in the ICESCR and patent standards (and flexibilities) as required by the TRIPS Agreement (Sect. 2). The relationship between ICESCR and TRIPS is further examined in Sect. 3, which asks whether a conflict can be identified. It is shown that tension between the two exists and Sect. 4 continues with the manner in which to resolve such tension. Consequently the two approaches to the human rights and IP interface-conflict and coexistence-are discussed in more detail in Sect. 5 on the principle of the primacy of human rights and Sect. 6 on the principle of systemic integration.

\section{The Right to Health and Patents}

In light of the question posed in this article, the first step is to define conflict. In its report on the fragmentation of international law the International Law Commission (ILC) raised the question of what is a conflict. ${ }^{19}$ It found that conflict could be interpreted strictly and more widely. A strict definition of conflict presumes 'that conflict exists if it is possible for a party to two treaties to comply with one rule only by thereby failing to comply with another rule'. ${ }^{20}$ Such a strict direct incompatibility of treaty terms is the traditional understanding of conflict, setting a rather high threshold for finding a conflict between treaties and is thus rightly considered to be unduly narrow. ${ }^{21}$ The ILC report, however, also finds that there are 'looser understandings' of what constitutes a conflict. ${ }^{22}$ Even though there is no strict incompatibility between treaty provisions, a treaty may frustrate the goals of another treaty. Therefore the report adopts a wide notion of conflict 'as the situation where two rules or principles suggest different ways of dealing with a problem'. ${ }^{23}$

\footnotetext{
18 See the response by the WTO to Resolution 2000/7 in UN Sub-Commission on the Promotion and Protection of Human Rights, 'Report of the Secretary General on Intellectual Property Rights and Human Rights', UN Doc. E/CN.4/Sub.2/2001/12; and the response by the World Intellectual Property Organisation in UN Sub-Commission on the Promotion and Protection of Human Rights, 'Report of the Secretary General on Intellectual Property Rights and Human Rights. Addendum', UN Doc. E/CN.4/ Sub.2/2001/12/Add.1. See further Helfer (2003) p. 49; Yu (2006-2007), p. 1077; Helfer and Austin (2011), p. 73.

19 International Law Commission (2006), para. 18.

${ }^{20}$ Ibid., para. 24.

21 Haugen (2007), p. 102; Hestermeyer (2007), p. 175.

22 International Law Commission (2006), para. 24.

23 Ibid., para. 25.
} 
The International Court of Justice (ICJ) has rarely addressed the issue of what constitutes a conflict of norms in international law, yet in the Jurisdictional Immunities of the State case the Court did state that there could be no conflict when two norms regulate different matters. ${ }^{24}$ Therefore it must first be assessed whether the allegedly conflicting norms address the same subject matter (ratione materiae), in addition to both applying to a state party at the same time (ratione personae, ratione temporis). ${ }^{25}$

The majority of the 161 WTO members ${ }^{26}$ (more than $80 \%$ ) are also parties to the ICESCR $^{27}$ and are therefore faced with possible conflicting norms between the TRIPS Agreement and ICESCR. Although the two treaties at a first glance seem to address different subject matters (the protection of human rights vs. the protection of IPRs) there are clear links between access to medicines, the right to health and patents for medicines as will be set out in the following sections.

\subsection{Access to Medicines and the Right to Health}

There are a number of sources that protect access to essential medicines. The most obvious and logical starting point being the right to health. The right to health is codified in a number of instruments, most notably Article 25 of the 1948 Universal Declaration of Human Rights (UDHR) and Article 12 of the ICESCR. ${ }^{28}$

Article 12.1 recognises the 'right of everyone to the enjoyment of the highest attainable standard of physical and mental health'. It is a fundamental right which does not entail a right to be healthy, but encompasses a number of freedoms and entitlements to enable individuals to attain their highest standard of health possible. Paragraph 2 lists (non-exhaustively) a number of elements of the right to health, including 'the prevention, treatment and control of epidemic, endemic, occupational and other diseases' and 'the creation of conditions which would assure to all medical service and medical attention in the event of sickness'. Today, the use of medicines is an essential and indispensable part of the treatment of diseases. Access to and the provision of medicines is, therefore, a vital element in enabling individuals to attain their highest attainable standard of health.

\footnotetext{
24 ICJ, Jurisdictional Immunities of the State (Germany v. Italy: Greece Intervening), Judgment of 3 February 2012, ICJ Reports 2012, p. 99, para. 93.

25 Haugen (2007), p. 104; Hestermeyer (2007), p. 174; Pauwelyn (2003), p. 165.

26 See the website of the WTO, http://www.wto.org/english/thewto_e/whatis_e/tif_e/org6_e.htm. Accessed 30 Aug 2015.

27 At the time of writing (August 2015) 164 states are party to the ICESCR. See the website of the UN Office of the High Commissioner for Human Rights, http://indicators.ohchr.org. Last accessed 30 Aug 2015.

28 In addition, health-related rights are also found in a number of international treaties specifically focusing on vulnerable groups; for example, Arts. 11.1(f), 12 and 14.2(b) of the 1979 Convention on the Elimination of All Forms of Discrimination Against Women and Art. 24 of the 1989 United Nations Convention on the Rights of the Child. In the regional context, one will also find human rights instruments which recognise health rights, such as Art. 11 of the revised 1961 European Social Charter, Art. 16 of the 1981 African Charter on Human and Peoples' Rights and Art. 10 of the Additional Protocol to the American Convention on Human Rights in the Area of Economic, Social and Cultural Rights.
} 
Article 2.1 ICESCR sets out the principal obligation requiring States Parties to progressively realise the rights laid down in the Covenant. In that regard they have a margin of discretion as long as they do so by all appropriate means and to the maximum of their available resources. In addition, Article 2.1 sets out obligations of a more immediate nature: namely, to undertake steps towards full realisation and, as stated in Articles 2.2 and 3 ICESCR, to respect and ensure the principle of nondiscrimination.

The Committee on Economic, Social and Cultural Rights (CESCR) - a committee consisting of independent experts which was set up to monitor the implementation of ICESCR - has interpreted the right to health and States Parties' obligations in its General Comment No. 14 on the Right to the Highest Attainable Standard of Health. ${ }^{29}$ Although formally not binding, it is an authoritative interpretation of States Parties' obligations under Article 12 ICESCR. ${ }^{30}$

According to the Committee, the right to health has four interrelated and essential elements: availability, accessibility (physical and economic), acceptability and quality; jointly known as the AAAQ framework. These criteria also apply to the provision of essential medicines as a vital component of the right to health. The focus in this article is on the element of 'economic accessibility' or, in other words, affordability.

As it has also done with respect to other rights, the Committee makes use of the tripartite typology of obligations: respect, protect and fulfil. ${ }^{31}$ The right to health, therefore, contains both positive and negative duties for States Parties. Moreover, the Committee considers the provision of essential medicines, as defined under the WHO Action Programme on Essential Drugs, to be part of the minimum core content of the right to health: those elements of a right without which the right would be devoid of any meaning or relevance. As a result, the Committee finds that 'a State Party cannot, under any circumstances whatsoever, justify its noncompliance with the core-obligations [...] which are non-derogable' 32 The Committee also recognises that in the spirit of Articles 55 and 56 of the UN Charter States Parties' obligations are not confined to the domestic context. For example, States Parties should ensure that due attention is given to the right to health in international agreements and in their actions as members of international organisations. $^{33}$

\footnotetext{
${ }^{29}$ CESCR, 'General Comment No. 14. The Right to the Highest Attainable Standard of Health', UN Doc. E/C.12/2000/4.

30 Vawda and Baker (2013), pp. 61-62; Tomuschat (2008), pp. 190-191; Sepúlveda (2003), p. 42; Craven (1995), p. 91. See also ICJ, Ahmadou Sadio Diallo (Republic of Guinea v. Democractic Republic of the Congo), Judgment of 30 November 2010, ICJ Reports 2010, p. 639, para. 66. There the Court stated, with respect to the jurisprudence including General Comments of the Human Rights Committee, that although it 'is in no way obliged [...] to model its own interpreation of the Covenant on that of the Committee, it believes that it should ascribe great weight to the interpretation adopted by this independent body that was established specifically to supervise the application of that treaty'.

31 CESCR, 'General Comment No. 14', UN Doc. E/C.12/2000/4, para. 33.

32 Ibid., para. 47.

33 Ibid., para. 39. See also the 2012 Maastricht Principles on Extraterritorial Obligations of States in the Area of Economic, Social and Cultural Rights, paras. 15, 17.
} 
Moreover, there is considerable state practice with regard to access to medicines, particularly in relation to HIV/AIDS, tuberculosis and malaria. ${ }^{34}$ The UN General Assembly has frequently stressed the importance of making anti-retroviral (ARV) medicines available at an affordable cost. ${ }^{35}$ With the adoption of the Millennium Development Goals the international community, though, has not limited its commitment to improving access to medicines only in the context of such pandemics. Most recently (October 2015) the adoption of the Sustainable Development Goals ${ }^{36}$ extends its commitment to ensuring healthy lives and promoting well-being including access to safe, effective, quality and affordable essential medicines and vaccines for all.

Finally, monitoring and accountability are integral features of a human rightsbased approach to health. ${ }^{37}$ Unfortunately, though, the UN human rights framework, although very successful in creating and developing human rights norms, has been less successful in providing effective enforcement mechanisms. The entry into force of an Optional Protocol to the ICESCR in May 2013, allowing individuals to bring a complaint directly before the CESCR, is an encouraging development in that regard. ${ }^{38}$

In conclusion, access to medicines is a right under international human rights law. For States Parties this entails an obligation of progressive realisation but also a more immediate, core obligation to provide essential medicines. In addition, States Parties, whether as members of international organisations or when interpreting and implementing international agreements, must ensure that the right to health is given due account. Consequently, members of the WTO should interpret and apply the TRIPS Agreement in a manner which is consistent with their right to health obligations. ${ }^{39}$ This could entail, for example, enabling and promoting the domestic manufacturing of cheaper (generic) medicines by making full use of the TRIPS flexibilities.

\subsection{The TRIPS Agreement: Patent Protection for Medicines}

The inclusion of IP within the framework of the WTO is one of the most significant developments in the area of international IP protection. As a single undertaking, the

\footnotetext{
34 Hestermeyer (2007), p. 129.

35 See for example UN General Assembly, 'Resolution S-26/2. Declaration of Commitment on HIV/ AIDS', UN Doc. A/RES/S-26/2 (2001); 'Resolution 60/262. Political Declaration on HIV/AIDS', UN Doc. A/RES/60/262 (2006); 'Resolution 65/277. Political Declaration on HIV/AIDS: Intensifying Our Efforts to Eliminate HIV/AIDS', UN Doc. A/RES/65/277 (2011).

36 UN General Assembly, 'Resolution 70/1. Transforming our World: the 2030 Agenda for Sustainable Development', UN Doc. A/RES/70/1 (2015).

37 Hunt and Leader (2010), p. 37.

38 At the time of writing (in August 2015) 21 States Parties to the ICESCR had ratified the Optional Protocol to the ICESCR. See the website of the UN Office of the High Commissioner for Human Rights, http://indicators.ohchr.org. Accessed 30 August 2015.

39 See also the 2012 Maastricht Principles on Extraterritorial Obligations of States in the Area of Economic, Social and Cultural Rights, para. 17.
} 
results of the WTO negotiations formed a single package to be implemented as one treaty, namely the Agreement Establishing the World Trade Organisationsigned in Marrakesh in 1994 and which entered into force on January 1st 1995. This WTO Agreement includes annexes on free trade in goods (General Agreement on Tariffs and Trade, GATT 1994), services (General Agreement on Trade in Services, GATS), IPRs (TRIPS), dispute settlement (Dispute Settlement Understanding, DSU) and a trade policy review mechanism. Consequently, potential members either had to accept all agreements or not become a member to the WTO.

The TRIPS Agreement is the first international agreement to comprehensively set out substantive and procedural minimum standards for the protection of IPRs. The WTO has widespread membership and, except for least developed members, all of these members are required to fully implement TRIPS, which has greatly influenced domestic developments in the field of patent protection for medicines. Furthermore, contrary to previous IP conventions, the agreements concluded within the WTO framework are subject to the robust dispute settlement mechanism of the WTO, a marked difference compared to the weak and rather ineffective monitoring system within the UN human rights framework.

Article 27 TRIPS introduced one of the major achievements of the TRIPS Agreement, namely the extension of patent protection to all fields of technology. As a result, members can no longer exclude medicines from patent protection. Articles 28 and 33 TRIPS oblige members to grant patent holders a set of exclusive rights (i.e. to prevent third parties from making, using, offering for sale, selling or importing for these purposes the patent product without consent) for a minimum period of 20 years.

In addition to these minimum standards, the TRIPS Agreement provides a degree of flexibility for members to balance patent protection with other public interests, including public health and access to medicines. Firstly, the object and purpose of the TRIPS Agreement-as can be found in its preamble and Articles 7 and 8 - does not limit itself to the protection of IPRs, but recognises the necessity to find a balance between the promotion of technological innovation and the transfer and dissemination of such technology. This is reflected in the wording of Article 7 TRIPS which was one of the main proposals made by developing countries during the negotiations and reads as follows:

The protection and enforcement of intellectual property rights should contribute to the promotion of technological innovation and to the transfer and dissemination of technology, to the mutual advantage of producers and users of technological knowledge and in a manner conducive to social and economic welfare, and to a balance of rights and obligations.

Article 8.1 TRIPS is formulated more strongly in that it states that 'members may [...] adopt measures necessary to protect public health [...] provided that such measures are consistent with the provision of this Agreement'.

Both articles are promising in that they provide flexibility to guarantee access to affordable medicines. On the other hand, their relevance is limited in that they cannot be interpreted as general exception clauses comparable to Article XX GATT 
(or Article XIV GATS). ${ }^{40}$ Thus, their importance, and that of the preamble too, lies in the fact that they set out the Agreement's objectives and principles, and thus provide the context for interpreting and implementing the TRIPS Agreement.

Secondly, the TRIPS Agreement leaves members free to determine the appropriate method of implementation within their national legal systems as long as TRIPS' minimum standards are guaranteed. ${ }^{41}$ Many of its provisions allow for a degree of interpretative flexibility, such as the terms 'novelty' and 'inventiveness' found in Article 27 TRIPS, which can be interpreted in a manner which is conducive to social welfare and public health.

Thirdly, in addition to the flexibility inherent in its objective to strike a balance, the TRIPS Agreement also provides a number of concrete options for developing members to balance patent protection with the right of access to medicines, particularly Articles 30 and 31 TRIPS. Consequently, within the limits of TRIPS, developing members can incorporate a number of tools to ensure that a balance is struck, such as a Bolar exception, ${ }^{42}$ compulsory licences (CL), ${ }^{43}$ and parallel importation. $^{44}$

Finally, the 2001 Doha Declaration on TRIPS and Public Health ${ }^{45}$ is the first public acknowledgment by the members of the WTO that there is a 'problem' and that 'the TRIPS Agreement does not and should not prevent Members from taking measures to protect public health' ${ }^{46}$ The Doha Declaration and the use of TRIPS flexibilities to protect public health will be further addressed below in Sect. 6.1.

In conclusion, the TRIPS Agreement sets out minimum standards which all WTO members (with the exception of least developed countries (LDCs)) must implement within their national systems. And although the TRIPS Agreement also provides flexibility, there is no doubt that it has significantly curtailed developing members' regulatory freedom with respect to patent protection for medicines.

\section{ICESCR-TRIPS: A Conflict?}

Having set out the international framework with respect to access to medicines, the right to health and patents the question arises whether - in this context - the right to health and patents conflict or coexist. The answer to this question depends on one's definition of conflict.

\footnotetext{
${ }^{40}$ Hestermeyer (2007), p. 58.

41 See Art. 1 TRIPS.

42 I.e. the use of a patented invention during the patent term for the purposes of seeking regulatory approval for the marketing of an equivalent generic version of the patented product once the patent term has expired.

43 I.e. a licence granted by the government authorising the use of a patented invention by a third party without authorisation of the right holder.

44 I.e. the importation of a patent-protected product into a country, without the authorisation of the right holder, once that product has been legally placed on a foreign market.

45 WTO, 'Doha Declaration on the TRIPS Agreement and Public Health Adopted at the Doha Ministerial Conference, Fourth Session', 2001, WT/MIN(01)/DEC/2.

46 Ibid., para. 4.
} 
To start with, there could be a strict conflict on the level of inconsistent obligations. If obligations are mutually exclusive this would entail that the implementation of TRIPS' obligations regarding patents makes it impossible to implement ICESCR's obligations regarding the right to health or vice versa. This is the traditional understanding of conflict and refers to a direct incompatibility of treaty terms, setting a rather high threshold for finding a conflict between treaties and is thus rightly considered to be unduly narrow. ${ }^{47}$ It is clear that the two treaties do not contain mutually exclusive obligations. ${ }^{48}$ The ICESCR and TRIPS set out a range of negative and positive obligations, yet both-although the ICESCR more so than TRIPS-allow States Parties to have flexibility in the manner of implementation.

Adopting a narrow, technical definition of conflict therefore leads to the conclusion that there is no conflict between the ICESCR and TRIPS. Yet this would be too easy a conclusion. Simply focusing on a technical definition of conflict ignores the complexity of the interface between patents and the right to health. As Pauwelyn has put it, 'one essentially solves part of the problem by ignoring it'. ${ }^{4}$ Consequently, a broader definition of conflict is adopted here, referred to as tension, in that both suggest different, arguably even contradictory, ways of dealing with the issue of access to medicines. ${ }^{50}$

Although not strictly incompatible, the object and purpose of both treaties are different. ${ }^{51}$ Simply put, the ICESCR focuses on human rights and human dignity and, in that regard, on access as a crucial element for the realisation of the right to health, while TRIPS focuses on striking a balance between access and protection within the framework of IPRs. Setting the two treaties in the context of their respective regimes, it is seen that the underlying values of the international trade regime and the international human rights regime are distinct. Both have different starting points and principal characteristics. ${ }^{52}$ The High Commissioner for Human Rights has noted that there remain 'fundamental differences of approach' between the two. ${ }^{53}$ The Special Rapporteur on the right to health has further noted that TRIPS bears upon crucial elements of the right to health. ${ }^{54}$

\footnotetext{
47 Papadopoulou (2011), pp. 286-287; Pauwelyn (2003), p. 170; Haugen (2007), p. 102; Hestermeyer (2007), p. 175. See for more information on why authors adopt a strict definition of conflict, Pauwelyn (2003), pp. 172-175.

48 Haugen (2007), p. 103; Papadopoulou (2011), p. 287.

49 Pauwelyn (2003), pp. 170-171.

50 International Law Commission (2006), para. 25.

51 Haugen (2007), p. 102.

52 Papadopoulou (2011), p. 270.

53 UN Sub-Commission on the Promotion and Protection of Human Rights, 'Report of the High Commissioner on the Impact of the Agreement on Trade-Related Aspects of Intellectual Property Rights on Human Rights', UN Doc. E/CN.4/Sub.2/2001/13, para. 22.

54 UN Commission on Human Rights, 'Report of the Special Rapporteur on the Right of Everyone to the Enjoyment of the Highest Attainable Standard of Physical and Mental Health, Paul Hunt, Submitted in Accordance with Commission Resolution 2002/31', UN Doc. E/CN.4/2003/58, para. 86.
} 
This tension between TRIPS and ICESCR has presented itself in different forms, such as in South Africa in the late 1990s when it decided to amend its legislation in order to promote access to medicines. ${ }^{55}$ Similarly India faced pressure for its introduction of section 3(d) to address 'ever-greening' in 2005 when Novartis filed a suit challenging this provision. ${ }^{56}$ In both of these cases, but also in many other situations worldwide, public pressure by civil society and health advocacy groups have opposed so-called TRIPS-plus developments to strengthen IPRs with considerable success. $^{57}$

Finally, an element of crucial importance in this discussion is enforcement. There are stark differences between the enforcement of TRIPS and international human rights law. TRIPS falls under the WTO dispute settlement mechanism and if a WTO member is found to be in violation of its obligations the Dispute Settlement Body may, as a last resort, authorise the complainant to withdraw trade or other concessions against the violator. ${ }^{58}$ The mere possibility of cross-retaliation is a powerful incentive, particularly for developing members, to comply with their TRIPS obligations. ${ }^{59}$ The ICESCR, on the other hand, does not have a very effective enforcement mechanism and, even though human rights are considered to be morally superior, the lack of enforcement gives them a weaker position compared to WTO rules. Consequently, it would make sense for (developing) members to lean more towards compliance with their obligations under TRIPS than under ICESCR.

Moreover, the WTO dispute settlement mechanism has not yet addressed the impact of human rights on the interpretation of TRIPS. More generally, there is a lack of explicit human rights references in the WTO Agreement, TRIPS, WTO jurisprudence and even the Doha Declaration on TRIPS and Public Health. The WTO adjudicative bodies can clarify and apply WTO law, but are not competent to give direct effect to international human rights law and formally interpret and enforce human rights treaties. ${ }^{60}$ This fragmentation within international law establishes a factual hierarchy, independent of any normative hierarchy. ${ }^{61}$

\footnotetext{
55 See Sect. 1.

56 The Novartis case will be further discussed in Sect. 6.2.

57 3D (2009); BUKO Pharma-Kampagne and Institute of Public Health Bengaluru (2011). See also Verger and Van Paassen (2013), p. 727.

58 See Art. 22 DSU.

59 Harrison (2007), p. 10; Vadi (2004), p. 202. It must be mentioned here, though, that to date crossretaliation has been rarely authorised. See Van Den Bossche and Zdouc (2013), p. 201.

60 Art. 3.2 DSU; WTO Appellate Body Report, Mexico-Tax Measures on Soft Drinks and Other Beverages, adopted 24 March 2006, WT/DS308/AB/R, paras. 56, 78.

61 Hestermeyer (2007), p. 170; Papadopoulou (2011), p. 289.
} 


\section{How to Resolve the Tension?}

It has been shown that with respect to access to affordable medicines in developing countries tension exists between the right to health (as found in the ICESCR) and the minimum standards of the TRIPS Agreement. There are a number of ways in which such tension can be dealt with.

International law contains a presumption against conflict. Thus one way in order to avoid tension between obligations is through treaty interpretation. ${ }^{62}$ In this way one interprets one norm in light of another norm in order to avoid a conflict. For example, where TRIPS leaves members with room to determine the exact manner in which to implement their obligations or where it contains vague terms that need clarification, the right to health may be resorted to in order to inform policy choices and to balance both obligations. ${ }^{63}$ Section 4 will address this-the coexistence approach-further.

If treaty interpretation cannot lead to avoiding the conflict, the conflict is no longer just apparent but genuine. In that case, a conflict must be resolved through a series of conflict resolution techniques, such as the lex superior derogat legi inferior (a superior norm prevails over an inferior norm), lex posterior derogat legi priori (a later expression of state prevails over an earlier expression), and lex specialis derogat legi generali (a special norm prevails over a general norm). As regards the latter two, the relevance of these techniques to actually resolve a conflict here is questionable. The lex posterior rule assumes that the conflicting norms emanate from the same lawmaker, which is often not the case, and as such this rule is rarely applied. ${ }^{64}$ This also holds true for the ICESCR and TRIPS, which do not stem from the same lawmaker. The lex specialis rule is only applicable in a situation of conflict between special and general international law, yet WTO law and international human rights law are both subsystems of general international law. A further limitation of these two rules, in this situation, is the nature of human rights treaties in that they are different from traditional international treaties consisting of mostly bilateral relations because they set out obligations of an objective nature excluding reciprocity. ${ }^{65}$ Consequently, with respect to the tension between the right to health and patent protection the lex posterior and lex specialis rules do not provide appropriate conflict resolution techniques.

The simplest way to resolve the tension between TRIPS and the right to health would be to establish that one of the two norms has a superior status under international law and that is exactly what some human rights bodies and commentators have argued for. Thus the principle of human rights primacy will be addressed in the following section.

\footnotetext{
62 Pauwelyn (2003), p. 244.

63 Seuba (2010), p. 201.

64 International Law Commission (2006), para. 234.

65 Seuba (2010), pp. 210-214.
} 


\section{The Principle of Human Rights Primacy}

The UN human rights system first addressed the interface between IP and human rights at the turn of the century. In a resolution adopted in 2000, the SubCommission on the Promotion and Protection of Human Rights (the SubCommission) was critical of the high level of IP protection required by the TRIPS Agreement declaring that:

since the implementation of the TRIPS Agreement does not adequately reflect the fundamental nature and indivisibility of all human rights, including the right of everyone to enjoy the benefits of scientific progress and its applications, the right to health, the right to food and the right to selfdetermination, there are apparent conflicts between the intellectual property rights regime embodied in the TRIPS Agreement, on the one hand, and international human rights law, on the other. ${ }^{66}$

Consequently, it reminds all governments of the 'primacy of human rights obligations over economic policies and agreements'. ${ }^{67}$ This statement by the SubCommission, however, does not have legal force as such since it is a non-binding instrument, but it did set out an ambitious new agenda for addressing IP issues within the UN human rights system. ${ }^{68}$

The two Special Rapporteurs appointed to undertake a study on the impact of globalisation on human rights were very critical of the WTO stating that the assumptions on which the rules of WTO are based are grossly unfair and even prejudiced' ${ }^{69}$ In their view, the primacy of international human rights law over all other regimes of international law is a basic and fundamental principle that should not be departed from. ${ }^{70}$ The WTO disagreed with the criticism and views the interface of IPRs and public interest as complementary rather than mutually exclusive, as reflected in Articles 7 and 8 of the TRIPS Agreement. ${ }^{71}$

International law recognises that certain norms are superior to others. Jus cogens or peremptory norms are norms 'accepted and recognised by the international community of states as a whole as a norm from which no derogation is permitted'. ${ }^{2}$

\footnotetext{
${ }^{66}$ UN Sub-Commission on the Promotion and Protection of Human Rights, 'Resolution 2000/7. Intellectual Property Rights and Human Rights', UN Doc. E/CN.4/SUB.2/RES/2000/7, para. 2. See for more information Weissbrodt and Schoff (2003); Weissbrodt and Schoff (2004).

67 UN Sub-Commission on the Promotion and Protection of Human Rights, 'Resolution 2000/7. Intellectual Property Rights and Human Rights', UN Doc. E/CN.4/SUB.2/RES/2000/7, para. 3. See further Yigzaw (2015), pp. 37-38; Alam et al. (2011), p. 74.

68 Helfer (2007), p. 986.

69 UN Sub-Commission on the Promotion and Protection of Human Rights, 'Preliminary Report Submitted by J. Oloka-Onyango and Deepika Udagama, in Accordance with Sub-Commission Resolution 1999/8 on Globalisation and Its Impact on the Full Enjoyment of Human Rights', UN Doc. E/CN.4/Sub.2/ 2000/13, para. 14

70 Ibid., para. 63.

71 UN Sub-Commission on the Promotion and Protection of Human Rights, 'Report of the SecretaryGeneral on Intellectual Property Rights and Human Rights', UN Doc. E/CN.4/Sub.2/2001/12, para. 7.

72 See Art. 53 of the Vienna Convention on the Law of Treaties (VCLT).
} 
Generally accepted examples include the prohibition of genocide, slavery, torture, racial discrimination and crimes against humanity. ${ }^{73}$ Others have added (the prohibition of gross violations of) the right to life, dignity and bodily integrity. ${ }^{74}$ The CESCR finds that the provision of essential medicines is part of the minimum core content of the right to health and, thus, a non-derogable obligation. ${ }^{75}$ International practice, though, suggests a narrow approach to the characterisation of jus cogens norms. ${ }^{76}$ There is no international consensus to extend jus cogens status beyond the prohibitions mentioned above to human rights in general, specific human rights-including the right to life-or certain elements of human rights. Moreover, it is rather questionable whether the determination by the CESCR that the core content of a right is non-derogable would lead to the conclusion that such core content is therefore a prioritised norm under international law. Firstly, the ICESCR itself does not formally prioritise certain elements of a right above others, nor does it include a provision similar to the ICCPR prohibiting derogations from the rights enshrined in the ICESCR. Quite the opposite, it provides for the possibility to impose limitations (Article 4 ICESCR). In addition, the Committee's General Comment No. 14, although an authoritative interpretation, is a formally non-binding instrument. Consequently, there is no evidence to suggest that the current list of accepted peremptory norms includes the right to health or a right of access to essential or even life-saving medicines. ${ }^{77}$

Furthermore, it has been argued that human rights as an emanation of UN Charter obligations would enjoy primacy on the basis of Article 103 of the UN Charter. ${ }^{78}$ Article 103 states that 'in the event of a conflict between the obligations of the members of the United Nations under the present Charter and their obligations under any other international agreement, their obligations under the present Charter shall prevail'. Obligations flowing from human rights treaties adopted within the UN framework, such as the ICESCR, are then considered to be obligations under the Charter, particularly under Articles 55 and 56, and would thus prevail over WTO obligations including TRIPS. However, this interpretation of Article 103 is not tenable. Article 103 gives primacy to those obligations expressly stated in the UN Charter and emanating from binding decisions by UN bodies, most notably Security Council resolutions adopted under Chapter VII, but not to human rights treaty obligations or non-binding resolutions adopted by UN human rights bodies. ${ }^{79}$

In conclusion, international law prioritises certain interests over others. The same is true for the CESCR's approach that prioritises certain elements of rights- the minimum core content of a right-as non-derogable obligations. However, nothing points to the conclusion that international law views human rights norms, except those few prohibitions of jus cogens status, as having a higher status compared to

\footnotetext{
73 International Law Commission (2006), paras. 374-376.

74 Forman (2011), pp. 158-159; Viljoen (2007), p. 28.

75 CESCR, 'General Comment No. 14', UN Doc. E/C.12/2000/4, para. 43.

76 Vidmar (2013), p. 22.

77 Harrison (2007), p. 58; Papadopoulou (2011), pp. 290-291.

78 Yigzaw (2015), pp. 62-63.

79 International Law Commission (2006), para. 331.
} 
any other norm of international law. ${ }^{80}$ For a norm to attain the status of jus cogens it must be recognised as such by the international community as a whole and there is no evidence to assume that the international community views the right to health and/or access to essential medicines to be of such a status. Consequently, any tension between the right to health and patents cannot be resolved by reference to the lex superior rule but must be resolved through treaty interpretation.

\section{The Principle of Systemic Integration}

In international law there is a strong presumption against conflict. It is assumed that when states create new obligations under international law, they do not derogate from their already existing obligations. ${ }^{81}$ Every sub-system of international law must be considered in the light of the wider corpus of general international law, including other sub-systems. ${ }^{82}$ The rules of treaty interpretation facilitate this process. Article 31.3(c) VCLT states that, together with the context, 'any relevant rules of international law applicable in the relation between the parties' shall be taken into account when interpreting a treaty. This is referred to as a 'principle of systemic integration' emphasising the unity of international law, where treaties are contextually interpreted taking account of a broader normative environment within international law. ${ }^{83}$ Article 31.3 (c) VCLT is seen as a linking device between disparate bodies of international law, and it is argued that it will enable the recognition of the right to health within TRIPS. ${ }^{84}$

Consequently, where possible, WTO norms should be interpreted in a manner so as to avoid any conflict or tension with other rules of international law. The assumption therefore is that the tension between TRIPS and the right to health is not a genuine conflict. Yet if a harmonious reading is not possible, the presumption against conflict is rebutted and a genuine conflict must be acknowledged. ${ }^{85}$

\subsection{Interpreting TRIPS in Light of the Right to Health}

The principal way, therefore, in which to avoid a genuine conflict between TRIPS and ICESCR is in interpreting the TRIPS Agreement in a manner which is conducive to promoting and protecting the right to health and access to medicines. ${ }^{86}$

\footnotetext{
${ }^{80}$ Hallo de Wolf (2013), pp. 199-200.

81 International Law Commission (2006), p. 37; Pauwelyn (2003), p. 207. See also ICJ, Right of Passage over Indian Territory-Preliminary Objections (Portugal v. India), Judgment of 26 November 1957, ICJ Reports 1957, p. 125, at p. 142. Here the ICJ found that 'it is a rule of interpretation that a text emanating from a government must, in principle, be interpreted as producing and intended to produce effects in according with existing law and not in violation of it'.

82 Pauwelyn (2003), p. 201.

83 Ibid., p. 253; International Law Commission (2006), paras. 413 et seq.

84 Forman (2011), p. 163.

85 Pauwelyn (2003), p. 251.

86 See for example Papadopoulou (2011), pp. 293-294; Wojahn (2001-2002), pp. 491 et seq.
} 
Within the WTO dispute settlement system international human rights law is not directly applicable. The WTO Appellate Body has however confirmed that WTO law cannot be read in clinical isolation from public international law and that WTO law should be interpreted according to customary rules of treaty interpretation, meaning Article 31 and 32 VCLT. $^{87}$ The WTO adjudicative bodies may therefore take account of human rights norms when interpreting TRIPS, yet some caution is required when drawing from an international agreement to which not all WTO members are party. ${ }^{88}$ Moreover, according to the WTO, the TRIPS Agreement promotes values which are essential for the realisation of human rights and aims at striking an appropriate balance between IP protection and human rights standards. ${ }^{89}$ Such a reading is also in line with the Doha Declaration on TRIPS and Public Health, which is explicit in the manner in which members should reconcile any tension between IPRs and public health. Paragraph 4 states that:

[...] the TRIPS Agreement does not and should not prevent Members from taking measures to protect public health. Accordingly, while reiterating our commitment to the TRIPS Agreement, we affirm that the Agreement can and should be interpreted and implemented in a manner supportive of WTO Members' right to protect public health and, in particular, to promote access to medicines for all.

In this connection, we reaffirm the right of WTO Members to use, to the full, the provisions in the TRIPS Agreement, which provide flexibility for this purpose.

Although implicitly, the Doha Declaration refers here to the promotion and protection of human rights. ${ }^{90}$ See for example the Special Rapporteur on the right to health who stated that '[i]n this way, the Declaration reflects human rights perspectives, especially the right to health and the right to enjoy the benefits of scientific progress' ${ }^{91}$ This balancing act, however, must take place at the national level and the value of the flexibility within TRIPS will depend mainly on the manner in which it is actually implemented by member states; an issue which will be further discussed below in Sect. 6.2.

The notion of balancing incentives with access is found within international human rights law. In her 2001 report, the High Commissioner for Human Rights,

\footnotetext{
87 WTO Appellate Body Report, United States—Standard for Reformulated and Conventional Gasoline, adopted 20 May 1996, WT/DS2/AB/R, p. 17.

88 WTO Appellate Body Report, European Communities and Certain Member States-Measures Affecting Trade in Large Civil Aircraft, adopted 1 June 2011, WT/DS316/AB/R, para. 844.

${ }^{89}$ See CESCR, 'Protection of Intellectual Property under the TRIPS Agreement. Background Paper Submitted by the Secretariat of the WTO', UN Doc. E/C.12/2000/18, paras. 13 et seq.

90 Seuba (2010), p. 214; Abbott (2006), p. 153.

91 UN Commission on Human Rights, 'Report of the Special Rapporteur on the Right of Everyone to the Enjoyment of the Highest Attainable Standard of Physical and Mental Health, Paul Hunt, Submitted in Accordance with Commission Resolution 2002/31', UN Doc. E/CN.4/2003/58, para. 87.
} 
in examining the relationship between the TRIPS Agreement and the right to health, found that the starting point for a human rights analysis of the TRIPS Agreement is Article 15 ICESCR (and Article 27 UDHR) which recognises the right of everyone to the moral and material interests resulting from any scientific, literary or artistic production of which he or she is the author and the right of everyone to enjoy the benefits of scientific progress and its applications. ${ }^{92}$ Article 15 ICESCR identifies the need to balance promoting general public interests in accessing new knowledge and protecting the interests of authors and inventors in such knowledge, and binds States Parties to achieve such a balance when designing an IP system. ${ }^{93}$

Balancing public and private interests is also not unfamiliar to IP laws. For example, with respect to patents, the monopoly position granted to a right holder is for a limited period and non-renewable, intended to provide inventors with the ability to recoup research and development costs; in return inventors must disclose their inventions, which has been a fundamental element of patent law since its inception. As such, patents aim to ensure access to the knowledge in the short term and access to the actual (patented) invention, and future inventions, in the long term. Consequently, the High Commissioner found a degree of compatibility between Article 15 and traditional IP systems, yet posited that the essential question is 'where to strike the right balance'. 94

General Comment No. 17 on the right of everyone to benefit from the protection of the moral and material interests resulting from any scientific, literary or artistic production of which he or she is the author (2005) further examines the relationship between Article 15 ICESCR with systems of IP protection. The CESCR states that the rights of authors under Article 15.1(c) ICESCR cannot be recognised in isolation of the other rights enshrined in the Covenant and that States Parties are therefore obliged to strike an adequate balance between the rights of authors and the other provisions of the Covenant. ${ }^{95}$ Moreover:

[i]n striking this balance, the private interests of authors should not be unduly favoured and the public interest in enjoying broad access to their productions should be given due consideration. States Parties should therefore ensure that their legal or other regimes for the protection of the moral and material interests resulting from one's scientific, literary or artistic productions constitute no impediment to their ability to comply with their core obligations in relation to the rights to food, health and education, as well as to take part in cultural life and to enjoy the benefits of scientific progress and its applications, or any other right enshrined in the Covenant.

\footnotetext{
92 UN Sub-Commission on the Promotion and Protection of Human Rights, 'Report of the High Commissioner on the Impact of the Agreement on Trade-Related Aspects of Intellectual Property Rights on Human Rights', UN Doc. E/CN.4/Sub.2/2001/13.

93 Ibid., para. 10.

94 Ibid., para. 12.

95 CESCR, 'General Comment No. 17. The Right of Everyone to Benefit from the Protection of the Moral and Material Interests Resulting from Any Scientific, Literary or Artistic Production of Which He or She Is the Author', UN Doc. E/C.12/GC/17 (2005), para. 35.
} 
The CESCR offers some specific recommendations to achieve such a balance-for example, States Parties have a 'duty to prevent unreasonably high costs for access to essential medicines' - stating that ultimately IP is a social product and has a social function. ${ }^{96}$

In his 2002 preliminary report, Special Rapporteur Paul Hunt also touched upon the relationship between TRIPS and human rights, stating that both Agreements (including GATS) bear upon crucial elements of the right to health. ${ }^{97}$ According to him international human rights law takes a position neither for nor against any particular trade rule or policy as long as in practice the rule or policy actually enhances the enjoyment of human rights and the process by which the rule or policy is formulated, implemented and monitored is consistent with democratic and human rights principles. ${ }^{98}$

Continuing Hunt's work, Special Rapporteur Anand Grover submitted a report to the Human Rights Council in 2009 exploring the impact of the TRIPS Agreement on access to affordable medicines. ${ }^{99}$ There he stated that 'from a right to health perspective, developing countries and LDCs should be enabled to use TRIPS flexibilities'. ${ }^{100}$ He referred to the following flexibilities which members should incorporate into their national laws: make full use of the transition periods; define the criteria of patentability; issue compulsory licences and provide for government use; adopt the international exhaustion principle to facilitate parallel importation; create limited exceptions to patent rights; and allow for opposition and revocation procedures.

What the (legal) consequences of these reports and recommendations are is unclear. Being non-binding they do not have any formal legal force. However, they do constitute authoritative interpretations of states' international human rights obligations. Moreover, these recommendations could lead to political and legal change by opening up the debate, questioning government officials on specific issues during the process of state reporting, and providing guidance for states wishing to implement a more human rights-friendly IP system. ${ }^{101}$

Thus, in line with the principle of systemic integration, a good faith interpretation of the TRIPS Agreement should lead to a reading of TRIPS' obligations in a way that is coherent with human rights law and the right to health of which the Doha Declaration is a good example. The success of such a coexistence approachwhether (developing) states are able to strike a balance between access to medicines

\footnotetext{
96 Ibid.

97 UN Commission on Human Rights, 'Report of the Special Rapporteur on the Right of Everyone to the Enjoyment of the Highest Attainable Standard of Physical and Mental Health, Paul Hunt, Submitted in Accordance with Commission Resolution 2002/31', UN Doc. E/CN.4/2003/58, paras. 86 et seq.

98 UN Commission on Human Rights, 'Report of the Special Rapporteur on the Right of Everyone to the Enjoyment of the Highest Attainable Standard of Physical and Mental Health, Paul Hunt. Addendum. Mission to the WTO', UN Doc. E/CN.4/2004/49/add.1 para. 11.

99 UN Human Rights Council, 'Report of the Special Rapporteur on the Right of Everyone to the Enjoyment of the Highest Attainable Standard of Physical and Mental Health, Anand Grover', UN Doc. A/HRC/11/12 (2009).

100 Ibid., para. 27.

101 Helfer (2007), pp. 999-1000.
} 
and patent protection-will however depend much on the implementation and interpretation of the TRIPS Agreement at the domestic level.

\subsection{Striking a Balance at the Domestic Level?}

Many areas of coexistence between human rights and IPRs have been analysed by commentators from a variety of different perspectives. ${ }^{102}$ The aim here is to analyse state practice regarding the interpretation and implementation of TRIPS from a right to health perspective. This is by no means an exhaustive examination but is intended to highlight some interesting examples of a coexistence approach so as to strike a balance between the right to health and access to medicines, on the one hand, and patent protection for such medicines, on the other, in a national (developing country) context.

The starting point is that with respect to IPRs a 'one size fits all' approach is undesirable. States have different levels of development and different needs. Striking a fair balance between incentives for inventiveness and creativity and the dissemination of creative and innovative productions is at the heart of IP policy. For a developing country to be able to maximise domestic welfare it must make a tradeoff between innovating and imitating; the difficulty is to get the balance right. For example, for a country like Uganda with almost no pharmaceutical manufacturing capacity it is unrealistic to aim at innovative pharmaceutical research and development; it is more realistic to begin with the small-scale production of generic medicines. For example, Uganda decided to start manufacturing ARVs through a joint venture between the Indian company Cipla and a Ugandan privately owned pharmaceutical corporation, Quality Chemicals Ltd, due to concerns about the long-term sustainability of importing medicines from India. ${ }^{103}$ Thus, a (developing) state may want to set different levels of IP protection for different industries, depending on where its comparative advantage lies and the particular domestic context. ${ }^{104}$

Yet, the conclusion of the TRIPS Agreement led to a great deal of concern as to how the establishment of global minimum levels of IP protection would affect developing countries' ability to improve public health, and more generally economic and technological development, particularly if introducing (product) patents for pharmaceuticals would increase medicine prices and limit the available sources of medicines. As also recommended by many international human rights bodies, the most pragmatic solution to address these concerns is to make full use of the flexibilities and transitional periods incorporated in the TRIPS Agreement; an approach that is in line with Articles 7 and 8 TRIPS and the Doha Declaration on TRIPS and Public Health.

India is an example of a country that has made full use of the transition period by providing product patent protection only in 2005 upon the expiry of its TRIPS

\footnotetext{
102 See for example Foster (2008); Anderson and Wager (2006); Matthews (2010b); Gervais (2008b).

103 Haakonsson and Richey (2007), p. 85.

104 Berger (2001-2002), p. 200; Matthews (2010a), p. 26.
} 
deadline. ${ }^{105}$ Until that time, it did not allow product patents to be granted to medicines (patents for pharmaceutical processes were allowed). As a result, it was able to develop a strong generic pharmaceutical industry. ${ }^{106}$

On the other side, even though it is a LDC and therefore not yet under an obligation to fully implement TRIPS, ${ }^{107}$ Uganda started the process of reforming its patent legislation in order to bring it into line with TRIPS' requirements early. The Uganda Law Reform Commission indicated that it might be politically advantageous, in order to promote (foreign) investment, to implement TRIPS before the expiry of the deadline. ${ }^{108}$ Although this position is understandable from a political perspective, it must be warned against relinquishing regulatory freedom easily without a thorough inquiry into its effects, both in the short and long term, on its ability to address socio-economic problems such as public health.

The TRIPS Agreement obliges members to give effect to its provisions, yet it also states that ' $[\mathrm{m}]$ embers shall be free to determine the appropriate method of implementing the provisions of this Agreement within their own legal system and practice'. ${ }^{109}$ Thus, developing members have a certain amount of freedom when implementing the TRIPS provisions, as long as they stay within the boundaries of TRIPS. Article 27.1 TRIPS lays down the provisions with respect to patentable subject matter and conditions for patentability. Even though it is no longer possible to exclude medicines from patent protection, Article 27.1 does not define the concepts of novelty or inventiveness and, subsequently, leaves considerable flexibility for WTO members to decide the manner in which to implement and interpret this obligation. ${ }^{110}$

For example, India's definition of 'inventive step' is unique in that it is stricter than in many other countries as it requires an invention to involve a 'technical advance', 'economic significance' or both, in addition to the fact that the invention is not obvious to a person skilled in the art. ${ }^{111}$

India has further made use of this flexibility by introducing a unique section regarding patentable subject matter. Section 3(d) is one of the most controversial and discussed amendments made to the Indian Patents Act. It was introduced due to fears surrounding the public health implications of so-called 'evergreening'. 112 A concern also recognised by the Indian Technical Expert Group on Patent Law Issues that stated that 'every effort must be made to provide drugs at affordable

\footnotetext{
105 Chaudhuri (2005), pp. 67-68; Mueller (2007), pp. 529-530.

106 Mey (2010), p. 411; George (2010), pp. 4-5.

107 WTO Council for Trade-Related Aspects of Intellectual Property Rights, 'Extension of the Transition Period under Article 66.1 for Least Developed Members', 2013, IP/C/64.

108 Uganda Law Reform Commission (2004), p. 50.

109 Art. 1.1 TRIPS.

110 Chaudhuri (2005), p. 71; Mueller (2007), p. 563.

111 See sections 2(1) and 7(1) of the Indian Patents Act. See further Patent Office India (2011), para. 08.03.03; Ho (2011), p. 97; Kapczynski (2009), p. 1593; George (2010), p. 8.

112 'Evergreening' refers to the practice of the pharmaceutical industry to effectively extend the term of protection for patented pharmaceuticals by obtaining related patents for minor modifications made to the original product, new delivery systems for the pharmaceuticals, or new uses of the pharmaceutical etc.
} 
prices to the people of India'. ${ }^{113}$ Firstly, section 3(d) prohibits patents for derivatives-i.e. new forms of known substances-except if it can be shown that they provide a significantly enhanced efficacy. This provision is unique and not found in any other patent regime. ${ }^{114}$ It makes the 'evergreening' of pharmaceutical patents almost impossible. Additionally, section 3(d) contains an absolute exception to patentability by stating that the mere discovery of any new property of, or new use for, a known substance is not considered patentable. ${ }^{115}$ India's restrictive position on this matter contrasts with the lenient approach in the US and Europe in patenting second or subsequent medical uses of known pharmaceuticals. ${ }^{116}$

Section 3(d) is a good and creative example of a coexistence approach to patents and human rights. By taking full advantage of the flexibility within TRIPS India purposefully chose to implement TRIPS in a manner that aims at striking a balance between TRIPS' minimum standards and protecting access to medicines in line with the right to health. This approach has, however, also received opposition and criticism as to the TRIPS compliant nature of these provisions. ${ }^{117}$ Novartis challenged the constitutionality and TRIPS compatibility of section 3(d) when the Indian Patent Office refused to grant it a patent for its cancer medicine, Gleevec. ${ }^{118}$ The case was litigated up to the Indian Supreme Court, which upheld the constitutionality of the provision (and found that it was not competent to decide on its TRIPS compatibility). ${ }^{119}$

The Indian Supreme Court was very much aware of the broader debate and controversy surrounding the case, acknowledging arguments made that India is under an obligation to faithfully comply with its treaty commitments (i.e. TRIPS) countered by arguments to protect India's status as 'the pharmacy of the world'. It found that here it was its task to strike a balance between the need to promote scientific and technological research and development while also keeping private monopoly to a minimum. ${ }^{120}$

\footnotetext{
${ }^{113}$ Mashelkar et al. (2006), para. 5.16; Mey (2010), p. 440; Kapczynski (2009), pp. 1590-1591; George (2010), p. 7; Matthews (2013), p. 7.

114 Mueller (2007), p. 550.

115 Ibid., p. 557; Khader (2009), pp. 69 et seq.

116 Mueller (2007), p. 557.

117 Ibid., p. 558; Ho (2011), p. 95. Moreover, according to an Indian technical expert group on patent law issues it would be inconsistent with TRIPS to limit the granting of patents for pharmaceutical substances to NCEs (i.e. New Chemical or Medical Entities) only. Yet, the report does not actually address whether, to this extent, the Patents Act is consistent with TRIPS; it states that there is a 'perception' that current provisions in the Patents Act could be held to be TRIPS inconsistent and that restricting patentability to NCEs could therefore have legal and scientific ramifications. One would assume, therefore, that section 3(d) does not limit patent protection to NCEs only. See Mashelkar et al. (2006), paras. 5.6-5.7.

118 Khader (2009), pp. 86 et seq.; Amin (2007).

119 Indian Supreme Court, Novartis AG v. Union of India \& Others, Civil Appeal Nos. 2706-2716, 2013.

120 Ibid., para. 4.
} 
The Supreme Court's verdict was hailed as a victory for patients' right of access to essential medicines by civil society. ${ }^{121}$ While the case was under review, domestic and international civil society and health groups organised a mass mobilisation engaging in media and legislative advocacy to raise awareness about the case and Novartis' actions. ${ }^{122}$

There are also a couple of exception provisions within TRIPS that could provide useful tools for developing countries in balancing access and patent protection, among them most notably Article 31 TRIPS referring to compulsory licensing. The use of a CL could be a valuable tool for developing and also developed countries to increase generic production, importation and/or domestic competition and thus to reduce medicine prices. Of course a patent holder, such as a pharmaceutical corporation, can always grant a third party a voluntary licence to produce or use its patented product or process. However, pharmaceutical corporations are not always willing to do so and in such situations the granting of a CL, or merely the threat thereof, can provide a useful tool. TRIPS leaves members free to determine the grounds upon which a CL might be granted. In light of the Doha Declaration, concerns regarding public health and access to medicines are without doubt a legitimate ground for compulsory licensing.

Article 31 TRIPS sets out a rather long list of requirements regarding the procedure and the scope of rights granted under a CL: the granting of a CL shall be considered on its individual merits; (except in the case of a national emergency or other circumstances of extreme urgency or in cases of public non-commercial use) efforts are made to obtain prior authorisation from the patent holder on reasonable commercial terms and conditions and such efforts have not been successful within a reasonable period of time; the patent holder must be paid adequate remuneration; a CL shall be limited by its purpose, non-exclusive and non-assignable; a CL is subject to judicial review; and predominantly for the supply of the domestic market. Yet, the use of compulsory licensing to introduce generic competition will only be effective as long as the procedure to receive a CL is simple and easy and the required royalty payments are reasonable so as to ensure generic production is still economically viable.

India-again - provides a good example of the implementation of TRIPS in light of public health concerns in that its Patents Act defines the 'reasonable period' in which an applicant must negotiate a voluntary licence with the patent holder, namely a period not ordinarily exceeding 6 months. ${ }^{123}$ Consequently, a pharmaceutical corporation which is unwilling to grant a voluntary licence cannot unduly delay the granting of a CL. Furthermore, the Indian Patents Act states, with regard to the required royalty payment, that it must be 'reasonable' having regard to 'the nature of the invention, the expenditure incurred by the patent holder in making the invention or developing it and obtaining a patent and keeping it in force, and other

\footnotetext{
121 See Médecins Sans Frontières, 'Indian Supreme Court Delivers Verdict in Novartis Case', http:// www.msfaccess.org/about-us/media-room/press-releases/indian-supreme-court-delivers-verdict-novartiscase. Accessed 15 April 2013.

122 George (2010), pp. 15-16.

123 Section 84(6)iv of the Indian Patents Act.
} 
relevant factors' while also ensuring that 'the patented articles are made available to the public at a reasonably affordable price'. ${ }^{124}$

Finally, concern was raised with respect to the requirement of Article 31(f) TRIPS that use under a CL must be 'predominately for the supply of the domestic market' and the usefulness of this tool for developing and least developed members without adequate pharmaceutical manufacturing capacity. As such, it is argued that Article 31 TRIPS failed in its purpose, because the countries which most need it are not able to take advantage of it. ${ }^{125}$ Those countries that do have sufficient domestic manufacturing capacity, like for example India and Brazil, are not able to authorise the production of cheaper generic medicines under a CL for export to least developed (or developing) countries. This problem was acknowledged in paragraph 6 of the Doha Declaration and since then this has been termed the 'paragraph 6 problem'. The Doha Declaration instructed the TRIPS Council to find an expeditious solution to this problem. Consequently, preceded by a statement by its Chairperson, the WTO General Council adopted a Decision on August $30^{\text {th }}$, 2003, implementing a system to allow WTO Members with insufficient or no manufacturing capacities in the pharmaceutical sector to make effective use of compulsory licensing under the TRIPS Agreement. ${ }^{126}$

The 2003 Decision is a temporary waiver of the limitation of Article 31(f) TRIPS and sets out a detailed mechanism under which an (eligible) WTO member may issue a CL in order to import medicines from another member which must also issue a CL specifically for the purpose of exporting the required medicines. In 2005 the WTO members approved an amendment to the TRIPS Agreement in the form of Article 31 bis in order to implement the system introduced by the 2003 Decision. $^{127}$ The TRIPS Agreement will be formally amended once two-thirds of the members have accepted the change. At the time of writing (in August 2015), 57 members have accepted the amendment. ${ }^{128}$ Until the TRIPS amendment enters into force the waiver introduced by the 2003 Decision will continue to apply.

The introduction of the waiver system, and more generally the Doha Declaration, is firstly an explicit acknowledgement that there is a problem with regard to TRIPS and public health. In addition, it shows that WTO members are-or at least have been-willing to amend the TRIPS Agreement in view of public health concerns. In that regard this is a step forward in that it provides further flexibility to developing members so as to better protect access to medicines; a positive development from a coexistence approach to TRIPS and the right to health.

\footnotetext{
124 Section 90(1)i \& iii of the Indian Patents Act.

125 Mercurio (2006), p. 7.

126 WTO General Council, 'Decision of 30 August 2003 on the Implementation of Paragraph 6 of the Doha Declaration on the TRIPS Agreement and Public Health', 2003, WT/L/540. See further Hestermeyer (2007), p. 261.

127 WTO General Council, 'Amendment of the TRIPS Agreement', 2005, WT/L/641. See further Gervais (2008a), pp. 396 et seq.

128 WTO, 'Intellectual Property: TRIPS and Public Health. Members accepting amendment of the TRIPS Agreement', http://www.wto.org/english/tratop_e/trips_e/amendment_e.htm. Accessed 31 August 2015.
} 
Unfortunately, though, there are serious concerns as to the usefulness and practical relevance of this system. ${ }^{129}$ After 10 years the amendment has still not been ratified by two-thirds of WTO members and, of those that have, only a few have passed legislation to implement the system, including Canada, the EU, Norway, Switzerland, China and India. ${ }^{130}$ It is argued that the mechanism introduced by the 2003 Decision is 'too complex to have an effective impact on price'. ${ }^{131}$ The mechanism is too burdensome especially for least developed but also for developing members to be a truly effective tool in removing barriers to access to affordable medicines. The many administrative conditions required to make use of the system will obstruct the very purpose underlying it. Moreover, since 2003 the system has only been used once. Namely, by Rwanda to import generic HIV/AIDS medicines from Canada and the process took around three years. ${ }^{132}$ Consequently, the system has not lived up to expectations that it would provide a useful tool for developing and particularly least developed members struggling with ensuring access to medicines.

In conclusion, this section highlighted some examples of state practice striking a balance between patents and access to medicines by interpreting the TRIPS Agreement in light of human rights standards, particularly the right to health.

\section{Conclusion}

This article posed the question whether the right to health and patents conflict or coexist. This question was examined from the perspective of the issue of access to affordable medicines in developing countries focusing on the right to health as set out in the ICESCR and patent standards (and flexibilities) as required by the TRIPS Agreement. In the strict sense, there is no conflict between the right to health and patents. ICESCR and TRIPS do not contain mutually exclusive obligations. However, it has been shown that tension arises from the application of both treaties. Moreover, the lack of an effective enforcement mechanism within the UN human rights system compared to the dispute settlement mechanism of the WTO creates a factual hierarchy in favour of WTO rules.

There are a number of ways in which such tension can be dealt with. The UN Sub-Commission for the Promotion and Protection of Human Rights has contended that human rights should enjoy primacy over patents, yet there is no evidence to

\footnotetext{
129 UN Human Rights Council, 'Report of the Special Rapporteur on the Right of Everyone to the Enjoyment of the Highest Attainable Standard of Physical and Mental Health, Anand Grover', UN Doc. A/HRC/11/12 (2009), para. 41; Ovett (2007), p. 178; Chaudhuri (2005), p. 113; Verma (2010), pp. 647-648.

130 See WTO, 'Intellectual Property: TRIPS and Public Health. Members' Laws Implementing the "Paragraph 6" System', http://www.wto.org/english/tratop_e/trips_e/par6laws_e.htm. Accessed 31 August 2015.

131 Ovett (2007), p. 178.

132 WTO, 'TRIPS: TRIPS and Public Health "Paragraph 6" System. Notifications by Importing WTO Members', http://www.wto.org/english/tratop_e/trips_e/public_health_notif_import_e.htm. Accessed 31 August 2015 .
} 
suggest that the right to health and/or access to essential medicines are considered prioritised norms under international law. The WTO disagreed and views IPRs and human rights as complementary.

In international law there is a strong presumption against conflict. Both WTO law and the ICESCR are sub-systems of international law, but that does not mean that they operate in isolation of each other. They must be applied in a normative environment and considered within the wider corpus of international law, including general international law and other sub-systems. This is facilitated by customary rules of treaty interpretation-Article 31.3(c) VCLT-and referred to as a principle of systemic integration. Therefore, a good faith interpretation of the relevant WTO and human rights provisions should lead to a reading of TRIPS' obligations which is coherent with human rights law, also within the WTO dispute settlement system.

This balancing act must also take place at the domestic level and the success of a coexistence approach-whether (developing) states are able to strike a balance between access to medicines and patent protection-will greatly depend on the actual implementation and interpretation by member states. TRIPS does not implement a 'one size fits all' approach to the protection of IPRs. There is no inherent or genuine conflict between the right to health and patents. A prodevelopment interpretation and implementation of the TRIPS Agreement should allow developing members to strike a balance between complying with their obligations under TRIPS and international human rights law. On the other hand, certain issues, such as the potential of the proposed amendment to the TRIPS Agreement, remain unresolved.

Moreover, the manner in which the TRIPS Agreement is at times interpreted is worrying in that attempts are made to limit developing members' freedom to fully utilise the manoeuvring room within the TRIPS Agreement. Developing members are often pressured by (some) developed states and pharmaceutical corporations to not take full advantage of TRIPS' flexibilities (and even accept TRIPS-plus arrangements). This continuing pressure leads to increased tension between the right to health and patents. Consequently, in light of states' right to health obligations, TRIPS' objectives and principles, the Doha Declaration on TRIPS and Public Health and from a coexistence approach to IP and human rights, members should, firstly, take full advantage of TRIPS' flexibility with a view to protecting public health and ensuring access to medicines for all and, secondly, fully respect other members' right to do so.

Open Access This article is distributed under the terms of the Creative Commons Attribution 4.0 International License (http://creativecommons.org/licenses/by/4.0/), which permits unrestricted use, distribution, and reproduction in any medium, provided you give appropriate credit to the original author(s) and the source, provide a link to the Creative Commons license, and indicate if changes were made.

\section{References}

3D (2009) Switzerland. Missing policy coherence: trade interests overriding right to health? Report submitted to the CESCR pre-sessional working group. 3D, Geneva 
Abbott FM (2006) TRIPS and human rights: preliminary reflections. In: Abbott FM, Breining-Kaufmann $\mathrm{C}$, Cottier $\mathrm{T}$ (eds) International trade and human rights: foundations and conceptual issues. University of Michigan Press, Ann Arbor, pp 145-170

Alam SA et al (2011) The General Agreement on Trade in Services (GATS), water, and human rights from the perspective of developing countries. Neth Int Law Rev 58:43-75

Amin T (2007) The patent challenge: protecting the public domain and access to affordable medicines. Initiative for Medicines, Access and Knowledge. http://static1.1.sqspcdn.com/static/f/129694/ 949605/1186010064353/Archipielago+-+I-MAK+Website.pdf?token=SK7dwCuL8J1\% 2BkdLJAn1eVjGwitE\%3D. Accessed 29 Oct 2015

Anderson RD, Wager H (2006) Human rights, development, and the WTO: the cases of intellectual property and competition policy. J Int Econ Law 9(3):707-747

Attaran A (2004) How do patents and economic policies affect access to essential medicines in developing countries? Health Aff 23(3):155-166

Berger JM (2001-2002) Tripping over patents: AIDS, access to treatment and the manufacturing of scarcity. Conn J Int Law 17:157-248

Borrell J-R (2007) Pricing and patent of HIV/AIDS drugs in developing countries. Appl Econ 39(4):505-518

Boseley S (2015) FDA approval of 'female Viagra' leaves bitter taste for critics. The Guardian, 19 August 2015. http://www.theguardian.com/science/2015/aug/19/fda-approval-female-viagra-critics-addyius-licence. Accessed 23 Oct 2015

BUKO Pharma-Kampagne, Institute of Public Health Bengaluru (2011) At any price? Examination of the business behaviour of Boehringer Ingelheim, Bayer and Baxter in India. Pharma-Brief Special vol 1. BUKO Pharma-Kampagne, Bielefeld and Institute of Public Health, Bengaluru. http://www.en. bukopharma.de/uploads/file/Pharma-Brief/E2011_01_special_India.PDF. Accessed 29 Oct 2015

Cameron A et al (2009) Medicine prices, availability and affordability in 36 developing and middleincome countries: a secondary analysis. Lancet 373:240-249

Chaudhuri S (2005) The WTO and India's pharmaceuticals industry. Patent protection, TRIPS and developing countries. Oxford University Press, New Delhi

Chirac P, Torreele E (2006) Global framework on essential health R\&D. Lancet 367:1560-1561

CIPR (2002) Integrating intellectual property rights and development policy. Report of the Commission on Intellectual Property Rights. UK Commission on Intellectual Property Rights, London

Craven MCR (1995) The International Covenant on Economic, Social and Cultural Rights: a perspective on its development. Oxford University Press, New York

Cullet P (2003) Patents and medicines: the relationship between TRIPS and the human right to health. Int Aff 79(1):139-160

Dommen C (2002) Raising human rights concerns in the World Trade Organisation: actors, processes and possible strategies. Hum Rights Q 24:1-50

Durojaye E (2008) Compulsory licensing and access to medicines in post Doha era: What hope for Africa? Neth Int Law Rev 55:33-71

Forman L (2011) An elementary consideration of humanity? Linking trade-related intellectual property rights to the human right to health in international law. J World Intellect Prop 14(2):155-175

Foster SE (2008) Prelude to compatibility between human rights and intellectual property. Chic J Int Law 9:171-211

George J (2010) India position paper. Lawyers Collective HIV/AIDS Unit, New Delhi

Gervais D (2008a) The TRIPS agreement: drafting history and analysis, 3rd edn. Thomson Reuters/Sweet \& Maxwell, London

Gervais D (2008b) The relationship between intellectual property and human rights. In: Torremans PLC (ed) Intellectual property and human rights. Enhanced edition of copyright and human rights. Kluwer Law International, Alphen aan den Rijn, pp 3-23

Grosse Ruse-Kahn H (2009) Policy space for domestic public interest measures under TRIPS. South Centre, Geneva

Haakonsson SJ, Richey LA (2007) TRIPS and public health: the Doha Declaration and Africa. Dev Policy Rev 25(1):71-90

Hallo de Wolf A (2013) Human rights and the regulation of privatised essential services. Neth Int Law Rev 60:165-204

Harrison J (2007) The human rights impact of the World Trade Organisation. Hart Publishing, Oxford Hassim A et al (2007) Health and democracy. Siber Ink, Westlake 
Haugen HM (2007) Patent rights and human rights: exploring their relationships. J World Intellect Prop 10(2):97-124

Helfer LR (2003) Human rights and intellectual property: conflict or coexistence? Minn J Law Sci Technol 5:47-61

Helfer LR (2007) Toward a human rights framework for intellectual property. Univ Calif Davis Law Rev 40(3):971-1020

Helfer LR, Austin GW (eds) (2011) Human rights and intellectual property: mapping the global interface. Cambridge University Press, New York

Hestermeyer H (2007) Human rights and the WTO: the case of patents and access to medicines. Oxford University Press, Oxford

Ho C (2011) Access to medicine in the global economy. International agreements on patents and related rights. Oxford University Press, New York

Hunt P, Leader S (2010) Developing and applying the right to the highest attainable standard of health. The role of the UN Special Rapporteur (2002-2008). In: Harrington J, Stuttaford M (eds) Global health and human rights. Legal and philosophical perspectives. Routledge, Abingdon, pp 28-61

International Federation of Pharmaceutical Manufacturers and Associations (2012) The changing landscape of access to medicines. Geneva. http://www.ifpma.org/fileadmin/content/Publication/ 2012/ChangingLandscapes-Web.pdf. Accessed 29 Oct 2015

International Law Commission (2006) Fragmentation of international law: difficulties arising from the diversification and expansion of international law. Report of the Study Group of the International Law Commission. Finalised by Martti Koskenniemi. UN Doc A/CN.4/L.682

Kapczynski A (2009) Harmonisation and its discontents: a case study of TRIPS implementation in India's pharmaceutical sector. Calif Law Rev 97:1571-1650

Khader FA (2009) The law of patents. With a special focus on pharmaceuticals in India. LexisNexis Butterworths Wadhwa Nagpur, Guragon

Kramer B (2007) Patentschutz und Zugang zu Medikamenten. Rechtliche und Ökonomische Implikation. Carl Heymanns Verlag, Cologne

Li X (2008) The impact of higher standards in patent protection for pharmaceutical industries under the TRIPS Agreement: a comparative study of China and India. The World Economy 31:1367-1382

Mashelkar RA, et al (2006) Report of the Technical Expert Group on Patent Law Issues. Government of India, Ministry of Commerce and Industry, Department of Industrial Policy and Promotion. http:// ipindia.nic.in/ipr/patent/mashelkar_committee_report.doc. Accessed 29 Oct 2015

Maskus KE (2009) A review of the economic literature. In: Meléndez-Ortiz R, Roffe P (eds) Intellectual property and sustainable development. Development agendas in a changing world. Edward Elgar Publishing, Cheltenham, pp 71-95

Matthews D (2010a) Patents in the global economy. A report to the Strategic Advisory Board for Intellectual Property Policy (SABIP). Legal studies research paper no. 73/2010. Queen Mary University of London, School of Law, London

Matthews D (2010b) Intellectual property rights, human rights and the right to health. In: Grosheide W (ed) Intellectual property rights and human rights: a paradox. Edward Elgar, Cheltenham, pp 118-139

Matthews D (2013) The right to health and patents. Legal studies research paper no. 156/2013. Queen Mary University of London, School of Law, London

MDG Gap Task Force (2012) Millennium Development Goal 8. The global partnership for development: making rhetoric a reality. United Nations, New York

Meier BM (2006) Employing health rights for global justice: the public health response to the insalubrious ramifications of globalisation. Cornell Int Law J 39:711-777

Mercurio B (2006) Resolving the public health crisis in the developing world: problems and barriers of access to essential medicines. Northwest J Int Hum Rights 5(1):1-40

Mey BP (2010) Unfettered consumer access to affordable therapies in the post-TRIPS era: a dead-end journey for patients? Kenya and India case studies. J World Intellect Prop 13(3):403-473

Mueller JM (2007) The tiger awakens: the tumultuous transformation of India's patent system and the rise of the Indian pharmaceutical innovation. Univ Pittsburgh Law Rev 68:491-641

Muzaka V (2009) Developing countries and the struggle on access to medicines front: victories won and lost. Third World Q 30(7):1343-1361

Ovett D (2007) Making trade policies more accountable and human rights consistent: a NGO perspective of using human rights instruments in the case of access to medicines. In: Benedek W et al (eds) Economic globalisation and human rights. Cambridge University Press, New York, pp 170-209 
Papadopoulou F (2011) TRIPS and human rights. In: Kur A, Levin M (eds) Intellectual property rights in a fair world trade system. Proposals for reform of TRIPS. Edward Elgar, Cheltenham, pp 262-307

Patent Office India (2011) Manual of patent office practice and procedure. The Office of Controller General of Patents, Designs and Trademarks. http://www.ipindia.nic.in/ipr/patent/manual/HTML\% 20AND\%20PDF/Manual\%20of\%20Patent $\% 20$ Office $\% 20$ Practice $\% 20$ and $\% 20$ Procedure $\% 20-\%$ 20pdf/Manual $\% 20$ of $\% 20$ Patent $\% 20$ Office $\% 20$ Practice $\% 20$ and $\% 20$ Procedure.pdf. Accessed 29 Oct 2015

Pauwelyn J (2003) Conflict of norms in public international law. How WTO law relates to other rules of international law. Cambridge University Press, New York

Scherer FM, Watal J (2001) Post-TRIPS options for access to patented medicines in developing countries. Commission on macroeconomics and health working paper series paper no. WG4:1. World Health Organization, Geneva

Sell SK (2001-2002) TRIPS and the access to medicines campaign. Wis Int Law J 20(3):481-522

Sepúlveda MM (2003) The nature of the obligations under the International Covenant on Econonomic, Social and Cultural Rights. Intersentia, Antwerp

Seuba X (2010) Mainstreaming the TRIPS and human rights interactions. In: Correa CM (ed) Research handbook on the protection of intellectual property under WTO rules. Intellectual property in the WTO, vol 1. Edward Elgar, Cheltenham, pp 192-215

Tomuschat C (2008) Human rights: between idealism and realism, 2nd edn. Oxford University Press, New York

Trouiller P et al (2002) Drug development for the neglected diseases: a deficient market and a publichealth policy failure. Lancet 359:2188-2194

Uganda Law Reform Commission (2004) A study report on industrial property law (patents, industrial designs, technovations and utility models). Law Com Pub no. 12. http://www.ulrc.go.ug/ulrcsite/ sites/default/files/ulrc_resources/Industrial\%20property\%20report_0.pdf. Accessed 29 Oct 2015

Vadi V (2004) Balancing the human right to health and intellectual property rights after Doha. Ital Yearb Int Law 14:195-223

Van Den Bossche P, Zdouc W (2013) The law and policy of the World Trade Organisation, 3rd edn. Cambridge University Press, New York

Vawda YA, Baker BK (2013) Achieving social justice in the human rights/intellectual property debate: realising the goal of access to medicines. Afr Hum Rights Law J 13:55-81

Verger A, Van Paassen B (2013) Human development vis-à-vis free trade: understanding developing countries' positions in trade negotiations on education and intellectual property rights. Rev Int Polit Econ 20:712-739

Verma SK (2010) The Doha Declaration and access to medicines by countries without manufacturing capacity. In: Correa CM (ed) Research handbook on the protection of intellectual property under WTO rules. Intellectual property in the WTO, vol 1. Edward Elgar, Cheltenham, pp 623-672

Vidmar J (2013) Rethinking jus cogens after Germany v. Italy: back to Article 53? Neth Int Law Rev 60: $1-25$

Viljoen F (2007) International human rights law in Africa. Oxford University Press, New York

Weissbrodt D, Schoff K (2003) Human rights approach to intellectual property protection: the genesis and application of Sub-Commission resolution 2000/7. Minn Intellect Prop Rev 5(1):1-46

Weissbrodt D, Schoff K (2004) The Sub-Commission's initiative on human rights and intellectual property. Neth Q Hum Rights 22(2):181-215

WHO (2011) The world medicines situation. Access to essential medicines as part of the right to health. World Health Organisation, Geneva

Wojahn PL (2001-2002) A conflict of rights: intellectual property under TRIPS, the right to health, and AIDS drugs. UCLA J Int Law Foreign Aff 6:463-497

Yigzaw DA (2015) Hierarchy of norms: the case for primacy of human rights over WTO law. Suffolk Transnatl Law Rev 38(1):33-68

Yu PK (2006-2007) Reconceptualising intellectual property interests in a human rights framework. Univ Calif Davis Law Rev 40:1039-1150

Yu PK (2007) Ten common questions about intellectual property and human rights. Ga State Univ Law Rev 23:709-753 